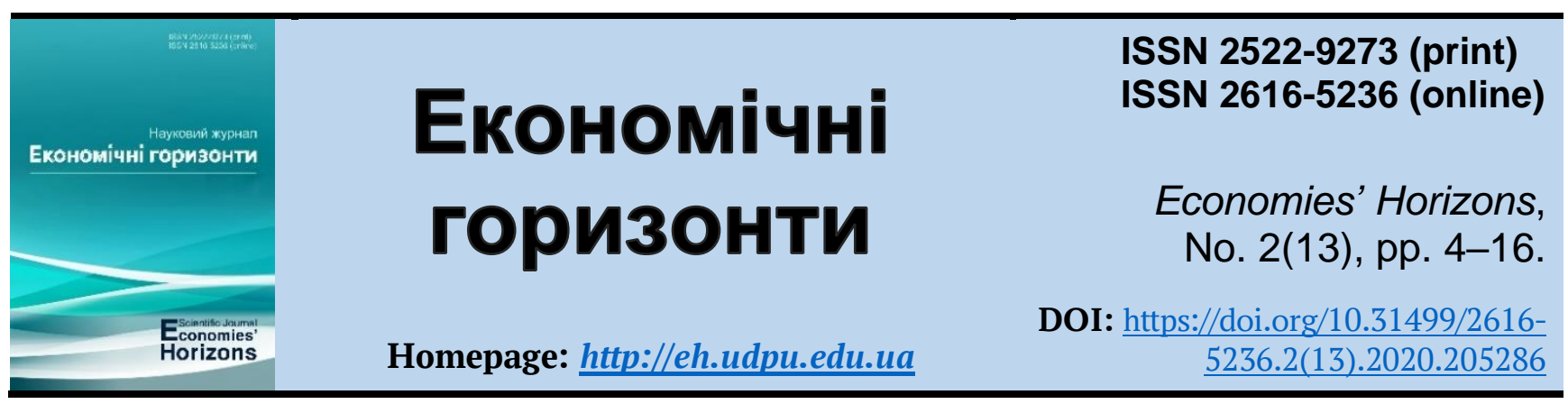

UDC 336.14:352]:336.153.5

\title{
Financial sustainability as a factor of forming fiscal space of local budgets
}

\author{
Taisiya H. Bondaruk ${ }^{1}$, Doct. Ec. Sc., Professor \\ Igor S. Bondaruk2 ${ }^{2}$ Cand. Ec. Sc., Associate Professor \\ Maksym V. Dubyna ${ }^{3}$, Cand. Ec. Sc.
}

Received: 27 April 2020

Accepted: 30 May 2020

\begin{abstract}
Bondaruk, T. H., Bondaruk, I. S. and Dubyna, M. V. (2020), "Financial sustainability as a factor of forming fiscal space of local budgets", Economies' Horizons, no. 2(13), pp. 416, doi: https://doi.org/10.31499/2616-5236.2(13).2020.205286.
\end{abstract}

Abstract. The purpose of the research is to deepen the theoretical foundations of financial stability as a factor in shaping the fiscal space of local budgets and substantiate the methodological tools for assessing the financial stability of local budgets of Ukraine in the medium and long term. Methods. The following research methods were used in analysing the problem: induction, deduction, system approach, statistical analysis, logical generalization, graphical method. Results. Fiscal extension gives the opportunities to local authorities to obtain and use extra budget resources for achieving the goal taking into account the restrictions caused by the necessity to maintain the financial sustainability in mid- and longterm periods. A methodological toolkit for assessing the financial sustainability of local budgets in midand long-term periods is proposed. The complex of arguments for the appropriate applying of the estimation of financial sustainability of local budgets in the national practice using the methodology of the European Commission in the mid-term period is given. It is substantiated that the development of strategic directions for ensuring the long-term financial sustainability of local budgets in Ukraine should take place with the use of foresight. It is substantiated that the fiscal space provides opportunities for local governments to obtain and use extra budgetary resources to achieve a certain goal, taking into account the constraints due to the need to maintain financial stability in the medium- and long-term periods. Methodical tools for assessing the financial stability of local budgets in the medium- and longterm periods are proposed. A set of arguments on the expediency of applying the methodology of the European Commission in the medium-term period in the native practice of calculating the financial stability of local budgets is presented. It is substantiated that the development of strategic directions to ensure long-term financial stability of local budgets of Ukraine should take place using foresight. Practical meaning. The practical significance of the obtained results is in the possibility of using methodological tools to assess the effectiveness of local budget sustainability management by state and local authorities in developing and making management decisions to regulate the level of financial stability

\footnotetext{
${ }^{1}$ National Academy of Statistics, Accounting and Audit; Head of the Department of Finances, Banking and Insurance; ORCID ID: https://orcid.org/0000-0001-9410-6428; e-mail: bondaruk23@ukr.net.

${ }^{2}$ Pavlo Tychyna Uman State Pedagogical University; Associate Professor at the Department of Marketing, Management and Business Management; ORCID ID: https://orcid.org/0000-0001-8960-7973; e-mail: bondarukigor@ukr.net.

${ }^{3}$ National Academy of Statistics, Accounting and Audit; Senior Lecturer at the Department of Finances, Banking and Insurance; e-mail: mdubina@ukr.net.
} 
of local budgets. Prospects for further research. The formation of theoretical foundations of financial stability as a factor in the formation of the fiscal space of local budgets and substantiation of methodological tools for their assessment in the medium and long term periods confirms the need for further scientific substantiation of strategic directions of long-term financial stability of local budgets in Ukraine under the condition of decentralization.

Keywords: fiscal extension, local budgets, financial sustainability, foresight, foresight tools, budget revenues, budget expenditures.

JEL Classification: E62, H61, H72, H77.

Number of references: 14; number of tables: 0; number of figures: $\mathbf{5}$; number of formulas: $\mathbf{0 .}$

\title{
Фінансова стійкість як фактор формування фіскального простору місцевих бюджетів
}

\author{
Таїсія Григорівна Бондарук ${ }^{1}$, д. е. н., професор \\ Ігор Сергійович Бондарук ${ }^{2}$, к. е. н., доцент \\ Максим Вікторович Дубина ${ }^{3}$, к. е. н.
}

Стаття надіŭшла: 27.04.2020

Стаття прийнята: 30.05.2020

\begin{abstract}
Bondaruk T. H., Bondaruk I. S., Dubyna M. V. Financial sustainability as a factor of forming fiscal space of local budgets. Економічні горизонти. 2020. № 2(13). С. 416. DOI: $\underline{10.31499 / 2616-5236.2(13) .2020 .205286 .}$
\end{abstract}

Анотація. Метою статті є поглиблення теоретичних засад фінансової стійкості як фактору формування фіскального простору місцевих бюджетів та обгрунтування методичного інструментарію оцінки фінансової стійкості місцевих бюджетів України у середньо- і довгостроковому періодах. Методи. При написанні статті використано наступні методи дослідження: індукції, дедукції, системного підходу, статистичного аналізу, логічного узагальнення, графічний метод. Результати. Обгрунтовано, що фіскальний простір надає можливості органам місцевого самоврядування в отриманні та використанні додаткових бюджетних ресурсів для досягнення визначеної мети з урахуванням обмежень, зумовлених необхідністю збереження фінансової стійкості у середньо- і довгостроковому періодах. Запропоновано методичний інструментарій оцінки фінансової стійкості місцевих бюджетів у середньо- і довгостроковому періодах. Наведено комплекс аргументів щодо доцільності застосування у вітчизняній практиці розрахунку фінансової стійкості місцевих бюджетів методики Європейської комісії у середньостроковому періоді. Обгрунтовано, що розробка стратегічних напрямів забезпечення довгострокової фінансової стійкості місцевих бюджетів України має відбуватися із застосуванням форсайту. Практичне значення одержаних результатів полягає у можливості використання методичного інструментарію оцінки результативності управління стійкістю місцевих бюджетів органами державної та місцевої влади при розробці та прийнятті управлінських рішень щодо регулювання рівня фінансової стійкості місцевих бюджетів. Перспективи подальших досліджень. Формування теоретичних засад фінансової стійкості як фактору формування фіскального простору місцевих бюджетів та

\footnotetext{
${ }^{1}$ Національна академія статистики, обліку та аудиту; завідувач кафедри фінансів, банківської справи та страхування; ідентифікатор ORCID: https://orcid.org/0000-0001-9410-6428; e-mail: bondaruk23@ukr.net.

${ }^{2}$ Уманський держсвний педагогічний університет імені Павла Тичини; доцент кафедри маркетингу, менеджменту та управління бізнесом; ідентифікатор ORCID: https://orcid.org/0000-0001-8960-7973; e-mail:bondarukigor@ukr.net.

${ }^{3}$ Національна академія статистики, обліку та аудиту; старший викладач кафедри фінансів, банківської справи та страхування; e-mail: mdubina@ukr.net.
} 
обгрунтування методичного інструментарію їх оцінки у середньо- і довгостроковому періодах підтверджує необхідність подальшого наукового обгрунтування стратегічних напрямів забезпечення довгострокової фінансової стійкості місцевих бюджетів України в умовах децентралізації.

Ключові слова: фіскальний простір, місцеві бюджети, фінансова стійкість, форсайт, інструментарій форсайту, доходи бюджету, видатки бюджету.

Кількість джерел: 14; кількість таблиць: 0; кількість рисунків: 5; кількість формул: 0.

\section{Introduction.}

In order to stabilize and ensure the sustainability of state and local finances, the Sustainable Development Strategy "Ukraine 2020" (President of Ukraine, 2015), the Program of Activities of the Cabinet of Ministers of Ukraine (The Verkhovna Rada of Ukraine, 2014) envisage: to establish mid-term budgetary forecasting and planning as well as strategic planning system; to change the legislation of Ukraine in the direction of controlling the revenues and expenditures of the state and local budgets; to regulate legislatively the issue of audit of local budgets and transparency of their reporting; to apply new approaches to local budgeting, to define the transfer policy principles and organize intergovernmental budgetary relations.

The directions of the aforementioned reforms of the system of state and local finances should be implemented through the management decisions with the reference to ensuring the financial sustainability of local budgets in Ukraine. This sustainability in the conditions of limited financial resources is largely determined by fiscal extending of local budgets, by the effectiveness of strategic directions of budgetary policy at the level of state and municipal authorities as well. The state of scientific development of the outlined issues causes the necessity to search for new effective methods and tools for assessing the financial sustainability of local budgets.

\section{Literature review.}

Some issues of assessment of financial sustainability of state and local finances were conducted in the works of G. Polyak (2000), I. Umanskyi (2015) and others. T. Yefymenko (2011) are devoted to the theoretical bases of fiscal space. The scientific works of the aforementioned scientists are focused mainly on the identification of general tendencies in the development of financial sustainability and fiscal space. Conceptual approaches to fiscal space of local budgets and the methodology of assessing the financial sustainability of local budgets in the mid- and long-term periods require development and implementation.

The aim of the study is to deepen the theoretical foundations of financial sustainability as a factor of fiscal space of local budgets and substantiate the methodological tools for assessing the financial sustainability of local budgets of Ukraine in the mid and long-term periods.

\section{Methodology.}

The following research methods were used in writing the article: induction, deduction, system approach, statistical analysis, logical generalization, graphical method.

\section{Research objectives.}

The research objective is to deepen the theoretical foundations of financial stability as a factor in the formation of the fiscal space of local budgets and substantiate the methodological tools for assessing the financial stability of local budgets of Ukraine in the medium and long term.

\section{Results and discussions.}

The financial sustainability of the local budget is characterized by various features, the most commonly interpreted is a set of monetary funds. Thus, according to G. Polyak, "the level of local budget sustainability is determined by the amount of funds needed to ensure minimum budget expenditures" (Polyak, 2000). I. Mykytiuk believes that the financial sustainability of the local budget is a state of set of monetary 
funds in which "the local authority has to develop steadily, providing its financial security in the conditions of extra level of risk. The conditions of financial sustainability of the local budget are: balance of revenue and expenditures for development; budgetary autonomy and solvency, which are characterized by the ability of the municipal authorities to mobilize financial resources into the budget without borrowing financial assistance, and to fulfil their powers fully and in a timely manner "(Mykytiuk, 2013, p. 87).

Sustainability of the local budget T. Korytko defines as the state of revenues and expenditures of the budget, their structures and dynamics, which provide local governments with the capability of full, timely and independent from other budgetary levels fulfilment of their duties, promotes balanced development of economy and social sphere (Korytko, 2008, p. 141-142).

When defining the concept of "financial sustainability of the local budget", it is necessary to take into account a set of characteristics obtained on the basis of a holistic assessment which includes: balance of revenues and expenditures of the budget; financial capability to withstand internal and external negative factors that affect social and economic development; budgetary autonomy and solvency; the ability of municipal authorities to provide timely financing of entrusted duties while maintaining their financial security at an additional level of risk (Bondaruk, 2017, p. 10).

Having studied the approaches to determining the essence of the financial sustainability of the local budget, it should be noted that today there is no consensus on the interpretation of this economic category. The content of the category "financial sustainability of the local budget" - is understood as a state of balance between revenues and expenditures of local budgets, which creates the possibility of full, timely fulfilment of the powers of local governments.

Fiscal extension is defined as the capability of the government to obtain and use extra budgetary resources to achieve a certain goal, taking into account the restrictions caused by the need to maintain fiscal sustainability in the mid- and long-term periods (Yefymenko, 2011, p. 12).

We propose to analyse the experience of supporting the sustainable state of public finances of EU countries. Problems of fiscal sustainability of public finances, as well as methodological approaches to determining the indicators of their evaluation are studied by experts of the International Monetary Fund and the European Commission (International Monetary Fund, 2010; European Commission, 2012). The main indicators of quantitative analysis of early warning systems (EWSs) are macroprudential supervision. Early warning (a preventive system) is a part of the evaluation system of financial sustainability used by the International Monetary Fund. The main target of this system is to generate appropriate indicators that can be changed mostly before fluctuations in overall economic activity. As a rule, the early warning system uses a system of indicators that are aggregated into a single consolidated indicator of the risk of a crisis (International Monetary Fund, 2010).

The directions of reforms of the local budget system should be implemented through management decisions with the reference to ensuring fiscal space of local budgets and their sustainability in Ukraine. Meanwhile, it is necessary to take into account the experience of supporting the sustainable state of public finances acquired by EU countries. Thus, the European Commission proposes to use the following indicators to calculate the fiscal sustainability of public finances: $S_{0}$-sustainability in a short-term period (current sustainability); $S_{1}-$ sustainability in a mid-term period; $S_{2}$ - sustainability in a long-term period (International Monetary Fund, 2010; European Commission, 2012).

Indicators $S_{1}$ and $S_{2}$ show a discrepancy between the projected (fixed period) government expenditures and the resource base that can be used to finance these expenditures. This discrepancy can be caused by excessive 
government expenditures and limited opportunities to increase their funding. According to I. Umanskyi, the growth of state revenues is complicated by the likelihood of slowing economic growth, limiting the use of additional mechanisms to increase indirect taxation, and public spending increases due to the negative impact of the aforementioned processes on economic growth and the growth of expenditures on social programs financing as well (Umanskyi, 2015, p. 21). The indicator $\mathrm{S}_{1}$ is used to determine the mid-term discrepancy in the sustainability of public finances. It shows the discrepancy between the expenditure and revenue parts of state administration sector which can appear for mid-term period.

Indicator $\mathrm{S}_{1}$ describes fiscal sustainability gap, that is, the difference between the ratio of revenue as a share of GDP and the amount of financing needed (relative to GDP), taking into account all possible revenues to the general government sector. Determining potential fiscal discrepancy opportunities projected and additional (potential) revenues to the general government sector are taken into account. Determination of fiscal discrepancy also involves the probable extra expenditures that may arise in the future (Umanskyi, 2015, p. 22).

In this study, we analyse the prognosticated indices of fiscal sustainability for the midterm period of $S_{1}$, calculated according to the International Monetary Fund in the EU Member States and in Ukraine as well for the period 2014-2030, which characterizes the data on financing public expenditures (Figure 1).

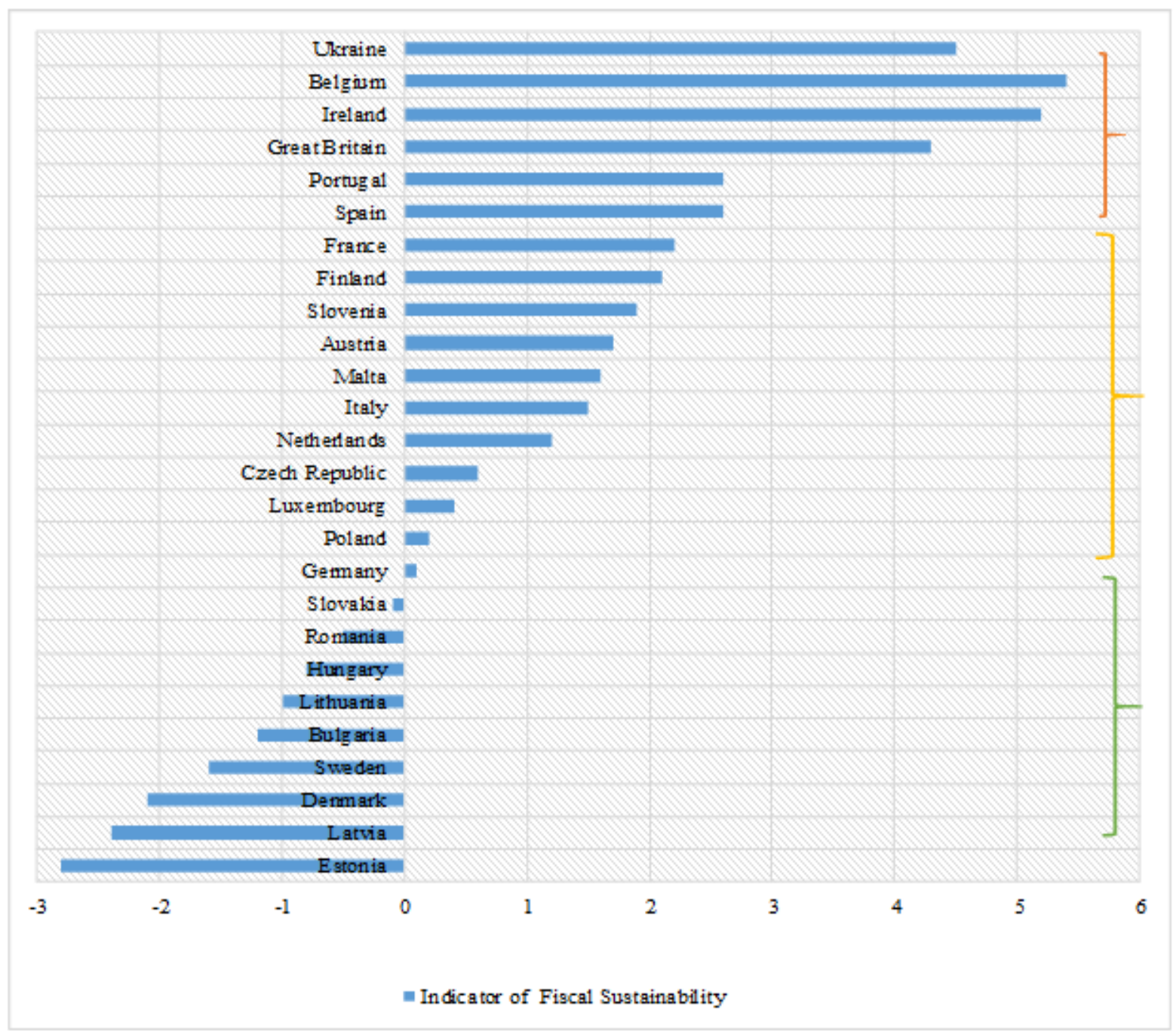

Fig. 1. Fiscal sustainability indicators in the mid-term period $\mathbf{S}_{1}$, in the EU Member States and in Ukraine (2014-2030), \% of GDP

Source: According to the authors (European Commission, 2014). 
The figure shows that for Ukraine the value of $S_{1}$ is $4.5 \%$ of GDP (see Figure 1).

Indicator $\mathrm{S}_{1}$ quantifies the fiscal discrepancy in the mid-term period which should be eliminated in order to restore the sustainability of public finances. The higher the value of $S_{1}$, the greater the adjustments of the primary structural balance are needed to ensure their sustainability (Umanskyi, 2015, p. 21). It is clear, that for the "red" zone countries the value of the indicator $S_{1}>2.5$ indicates a high level of mid-term fiscal risk. Ukraine ranks third among the countries in the "red" zone, this indicates a high level of mid-term fiscal risk. An indicator of $S_{1}$ from 0 to 2.5 in the mid-term indicates the average level of fiscal risk for the "yellow" zone countries, an indicator of $S_{1}$ less than 0 indicates a low level of fiscal risk for the "green" zone countries.

The next step is to analyse the indicator of fiscal sustainability in the long-term period of $\mathrm{S}_{2}$, in the EU Member States and in Ukraine (Figure 2).

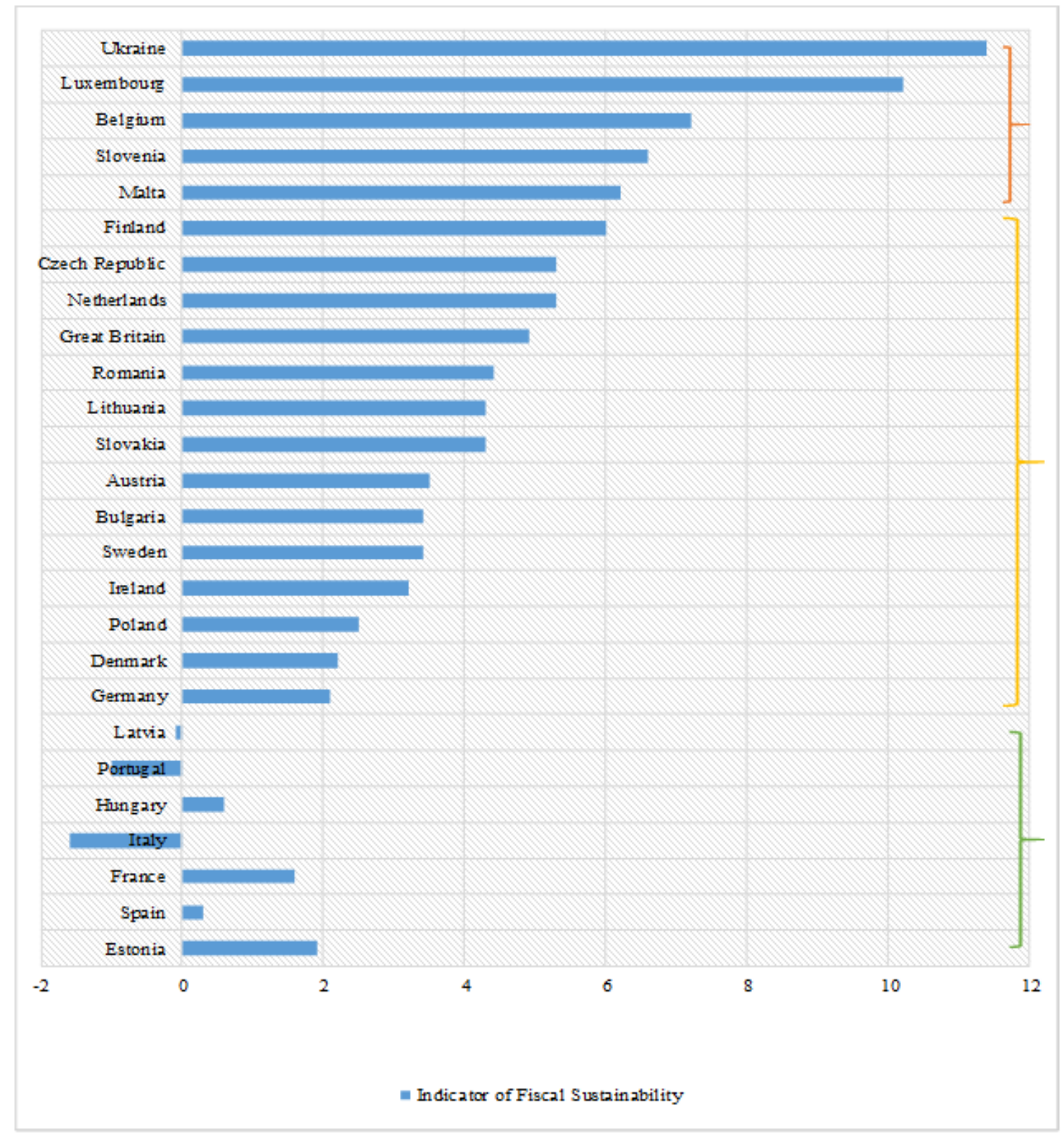

Fig. 2. The indicator of fiscal sustainability in the long-term period of $\mathbf{S}_{2}$, in the EU Member States and in Ukraine (2014-2060), \% of GDP

Source: Made by the authors according to (European Commission, 2014; Umanskyi, 2015). 
For the "red" zone countries, the value of $\mathrm{S}_{2}>6.0$ indicates a high level of long-term fiscal risk (Umanskyi, 2015, p. 23). In the longterm period, a value of $S_{2}$ ranging from 2.0 to 6.0 indicates an average level of fiscal risk for countries in the "yellow" zone, and for countries of the "green" zone a value of the indicator $S_{1}$ less than 0 indicates a low level of fiscal risk. For Ukraine, which ranks first among the analyzed countries in the "red" zone, the value of $\mathrm{S}_{2}$ has a twofold increase and exceeds the limit of the permissible level $\left(S_{2}>6,0\right)$ and indicates a high level of long-term fiscal risk.

The indicator $\mathrm{S}_{0}$ demonstrates the sustainability of public finances in the short-term period. The methodology for determining $\mathrm{S}_{0}$ does not measure the quantitative value of the required budget adjustment as a method for calculating $S_{1}$ and $S_{2}$. In calculating $S_{0}$, a significant number of macro-financial indicators are used.

When exceeding the fiscal discrepancy in indicators established by the government, measures of fiscal regulation are used to limit such a discrepancy and to achieve a sustainable state of public finances.

The methodology to calculate the sustainability of public finances found by the European Commission is used to calculate the sustainability of Ukraine's local budgets in the mid-term period $\left(\mathrm{S}_{1}\right)$.

In view of the fact that the indicator $S_{1}$, which is used to determine mid-term sustainability, characterizes the difference between the ratio of revenue as a share of GDP and the amount of financing needed (relative to GDP), first and foremost we analyze the dependence of changes in local budget expenditure (relative to GDP) on their own revenue as a share of GDP based on the construction of the regressive model. The logarithmic trend of sustainability of local budgets in Ukraine in the mid-term period $\left(\mathrm{S}_{1}\right)$ is shown in Figure 3. Its indicators demonstrate a downward trend in the sustainability of local budgets in Ukraine in the mid-term period, they showed a decrease in the degree of sustainability of local budgets of Ukraine.

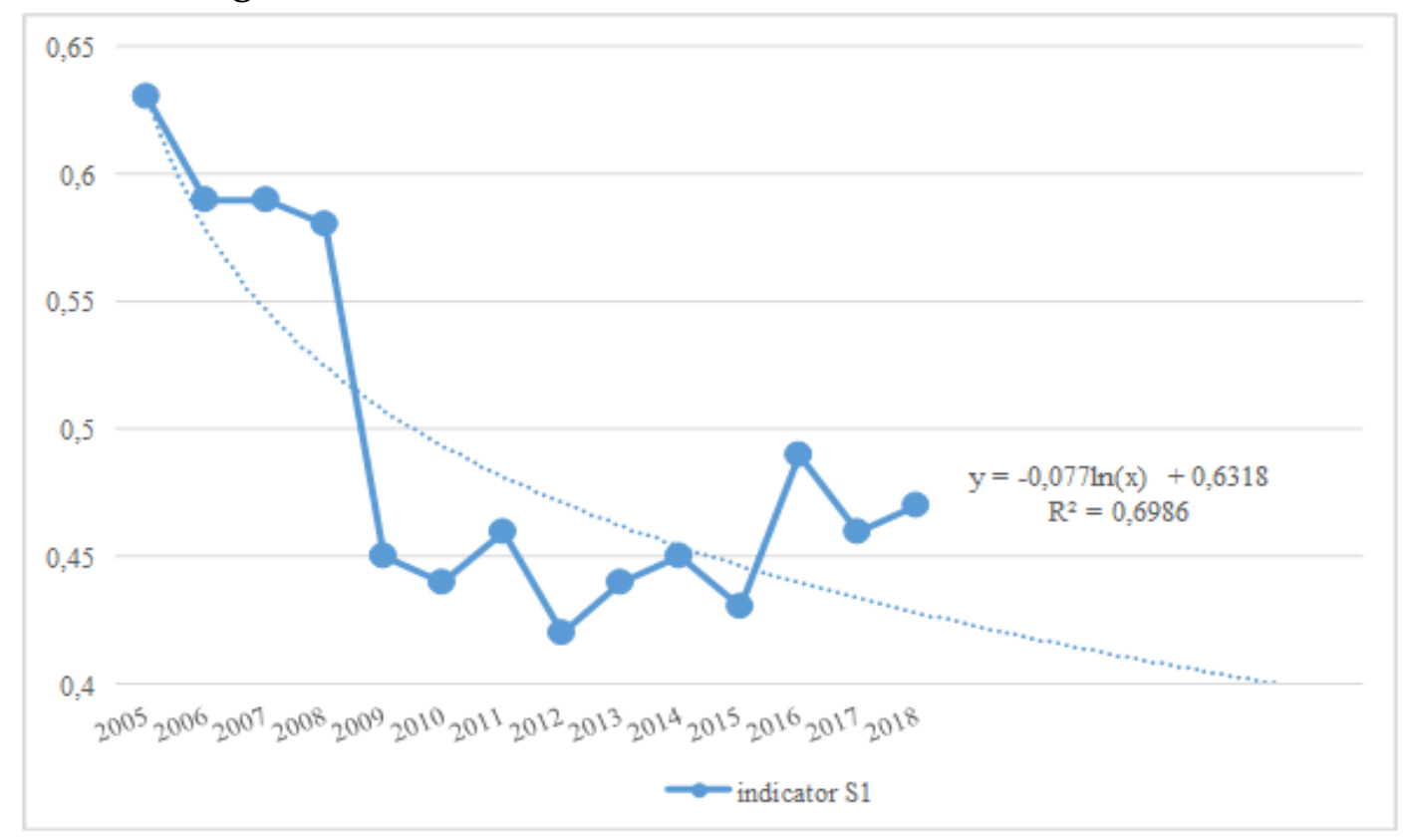

Fig. 3. Logarithmic trend of financial sustainability of local budgets of Ukraine in the mid-term period $\left(\mathbf{S}_{1}\right)$

Source: Compiled by the authors based on their own calculations.

However, we consider that the method of determining the mid-term sustainability discrepancy by characterizing the difference between the ratio of revenues to budget expenditures (relative to GDP) is too simplistic. This methodology does not take into account the indicators of the financial capacity of the budget, its autonomy, efficiency, debt 
strain and other factors, including changes in the formation of revenues and expenditures of local budgets due to the possible prospects for innovative development in the particular territory and the possible positive or negative consequences for the development of the territorial community in the conditions of decentralization.

To form an assessment of the possible future sustainability of local budgets, we propose to use a foresight methodology. Foresight (to predict what will happen or be needed in the future) is defined as a technology for the practical application of substantial prediction.

Foresight is widely used in public administration and in the development of strategies, projects and programs for regional and local development (Boothe, 2003). The most common definitions of foresight are as following: systematic attempts to evaluate the long-term perspectives of science, technology, economics and society, in order to identify strategic areas of research and new technologies which are capable to deliver the greatest socio-economic benefits; forecasting, technology assessment, research in future and other forms of foresight are an attempt to identify long-term trends and coordinate decision-making based on them (Serohin and Sharov, 2016, p. 127).

The difference between foresight and other forecasting mechanisms is that, unlike forecasts that are mostly correlated with forecasts of unmanaged events, the potential prospects for innovative development in the particular territory and the positive consequences for the development of the territorial community are assessed within the foresight.

We believe that the development of strategic directions for ensuring the long-term financial sustainability of local budgets in Ukraine in the context of decentralization should be applied with the mandatory use of foresight for each budget of the territorial community, district, and region. Taking into account the uneven social and economic development of regions and territorial communities, foresight development that meets the needs of each region or territorial community is quite a challenge. That is why we propose the foresight methodology of financial sustainability of local budgets based on the use of the Delphi method and the SWOT-analysis method. This foresight methodology can be used in the midand long-term periods to calculate the sustainability of local budgets of Ukraine at the level of regions or territorial communities.

An important condition for the effectiveness of the foresight is the groups formation of highly qualified experts who are representatives of government and municipal authorities, business, scientists, public organizations, who would be interested in its effective implementation. Foresight technology consists of a system of methods, tools, techniques that are developed in different scientific fields and allow not only to anticipate problems of future development, but also to influence them, harmonizing the private interests of different segments of society (Zhurovskyi, 2015).

Foresight methodology is determined depending on the purpose and objectives, as well as the industry in which it is used. Foresight is a system of methods of expert evaluation of strategic directions of social and economic, as well as innovative development, identification of technological breakthroughs that can influence the development of a region or territory in the mid- and long-term perspective. The most common of them are as following: Delphi method, SWOT-analysis method, the development of events, mathematical modeling, collective idea generation ("brainstorming"), regressive analysis, prognosticative extrapolation.

The algorithm for the foresight methodology of local budget sustainability using expert evaluation method (Delphi method), scenario planning methods and SWOT-analysis methods with a certain sequence of its implementation, with possible scenarios of ensuring the financial sustainability of local budgets of Ukraine in the mid- and long-term horizons are given in Figure 4. 


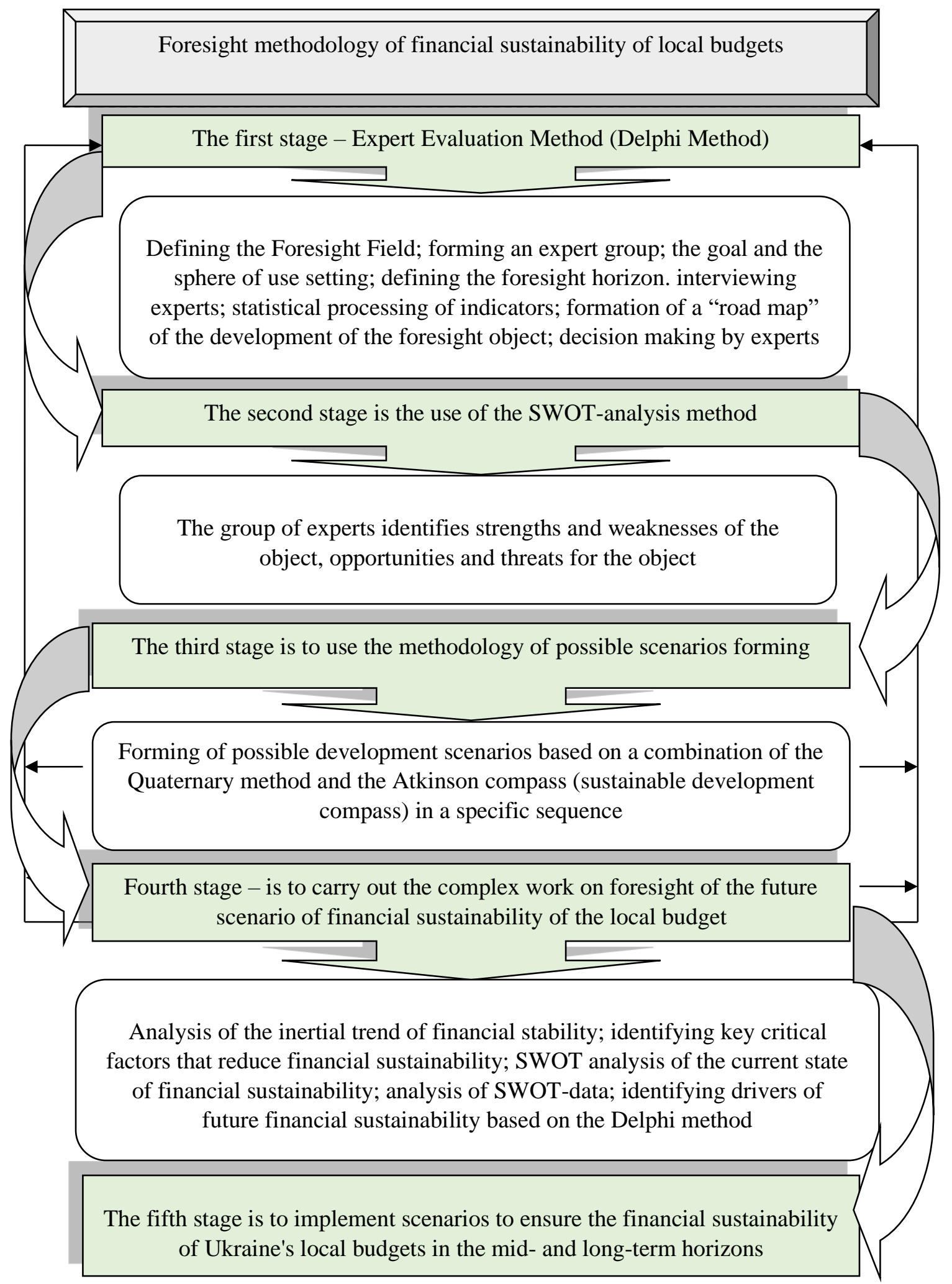

Fig. 4. Algorithm of the foresight methodology of local budgets financial sustainability

Source: Developed by the authors.

The first stage of researches of the proposed foresight methodology is conducted using the Delphi method, according to which the research is carried out in a specific sequence (determining the field of foresight; forming a group of experts - experts on the topic; setting the goal to be achieved by solving the problem; determining the sphere of the use; determining 
the foresight horizon; setting up a survey form for experts; inquiry for experts; statistical processing of survey indicators to obtain new results; analysis and correction (if necessary) of the answer and the conclusion of the group by each expert of the obtained results; re-processing of the inquiry data taking into account their correction; if necessary re-doing the analysis and correcting to achieve the consistent answers (consensus result); forming directions of primary importance ("road map") to develop a foresight object; making a consensus decision by experts based on a collective analysis of the results obtained).

First and foremost, in the foresight methodology, it is necessary to define the foresight field, its goal, the scope of the use for forming a view as to the prospects of local budgets development in the future, particularly their financial sustainability in the mid- and longterm period as well. The foresight field outlines the project participants and is formed of several groups, which include specialists in this field and organizations, institutions that are directly interested in the foresight implementation (Serohin and Sharov, 2016, p. 130131).

An important part of a foresight organization is the scope of the use, that is, the plan of optimal resolution of the project goal (it is necessary to determine the decisive moments in community development, what recessive elements are suitable to be transformed into dominant ones). For example, it is not necessary to predict the prognostication of a significant number of indicators that affect the financial sustainability of local budgets, it is enough to identify two-three key factors affecting the financial sustainability of local budgets and for them the foresight toolkit should be used.

The foresight horizon is a period of time the fixation of the prognostication results or an active prediction is oriented to. It is determined individually, depending on the type of foresight chosen (Serohin and Sharov, 2016, p. 131). The foresight horizon can be defined as the maximum number of years of active prediction. The time horizon involves two processes. One of them sets the optimal time horizon and provides prospects, in particular decentralization as in our case. The essence of the second process is to determine the priority directions of the object development, which are determined in the formation of a "road map". Based on the developed roadmap, strategies and long-term priorities for the development of territorial communities are formulated, with a detailed description of the main stages and possible mechanisms for its achievement.

The second stage of the researches of the proposed foresight methodology is carried out using the SWOT-analysis method. For this purpose, a group of experts is formed - experts of high professional level in the field of local budgets and social-economic development of the territorial communities of Ukraine (experts of group B). This experts team identifies strengths, weaknesses, object characteristics, opportunities, and threats to the object. The results of the SWOT-analysis (no more than two to four for each group of factors) are used to work out scenarios for the development of the territories of Ukraine in the mid- and long-term time horizons.

At the third stage of researches of the foresight methodology the technique of constructing possible scenarios for ensuring the financial sustainability of local budgets of Ukraine and developing scenarios for its possible development are used. Scenarios for ensuring the financial sustainability of local budgets can be based on a combination of two methods, such as the quaternary method and the Atkinson Compass (Sustainable Development Compass).

At the fourth stage of researches, a series of works on the foresight of the future scenario of financial sustainability of the local budget is carried out: analysis of the inertial trend of financial sustainability is done; key critical factors that reduce financial sustainability are identified; SWOT-analysis of the current state of financial sustainability is conducted; the SWOT-examination data for the current state 
of financial sustainability is analyzed; determinant drivers of future financial sustainability based on the Delphi method are identified.

The fifth stage of researches of foresight methodology involves the scenarios development for ensuring the financial sustainability of local budgets of Ukraine in the mid- and long-term time horizons.

The use of the developed foresight methodology of estimating financial sustainability of local budgets of Ukraine in the mid- and long-term time horizons permits: to expand the toolkit of assessment of financial sustainability of local budgets in the mid- and long-term periods; to identify risks to the financial sustainability of local budgets and take timely measures to strengthen certain toolkit to achieve the goals and objectives; to determine the effectiveness of the use of existing tools for assessing the financial sustainability of local budgets in the mid- and long-term periods; to conduct a comparative analysis of the financial sustainability of local budgets of different regions and territorial communities; it is reasonable to determine the scenarios for ensuring the financial sustainability of the local budget and to evaluate the possibility of increasing its level of financial sustainability in the mid- and long-term periods.

Taking into account the fact that most of key risks of forming fiscal space of local budgets and their financial sustainability are a significant shadow sector in the Ukrainian economy and corruption in the country. Based on regressive analysis we determine the dependence of changes in local budget revenues on the volume of the shadow sector in GDP and the scale of corruption in the economy of Ukraine based on the development of the regressive model (Figure 5).

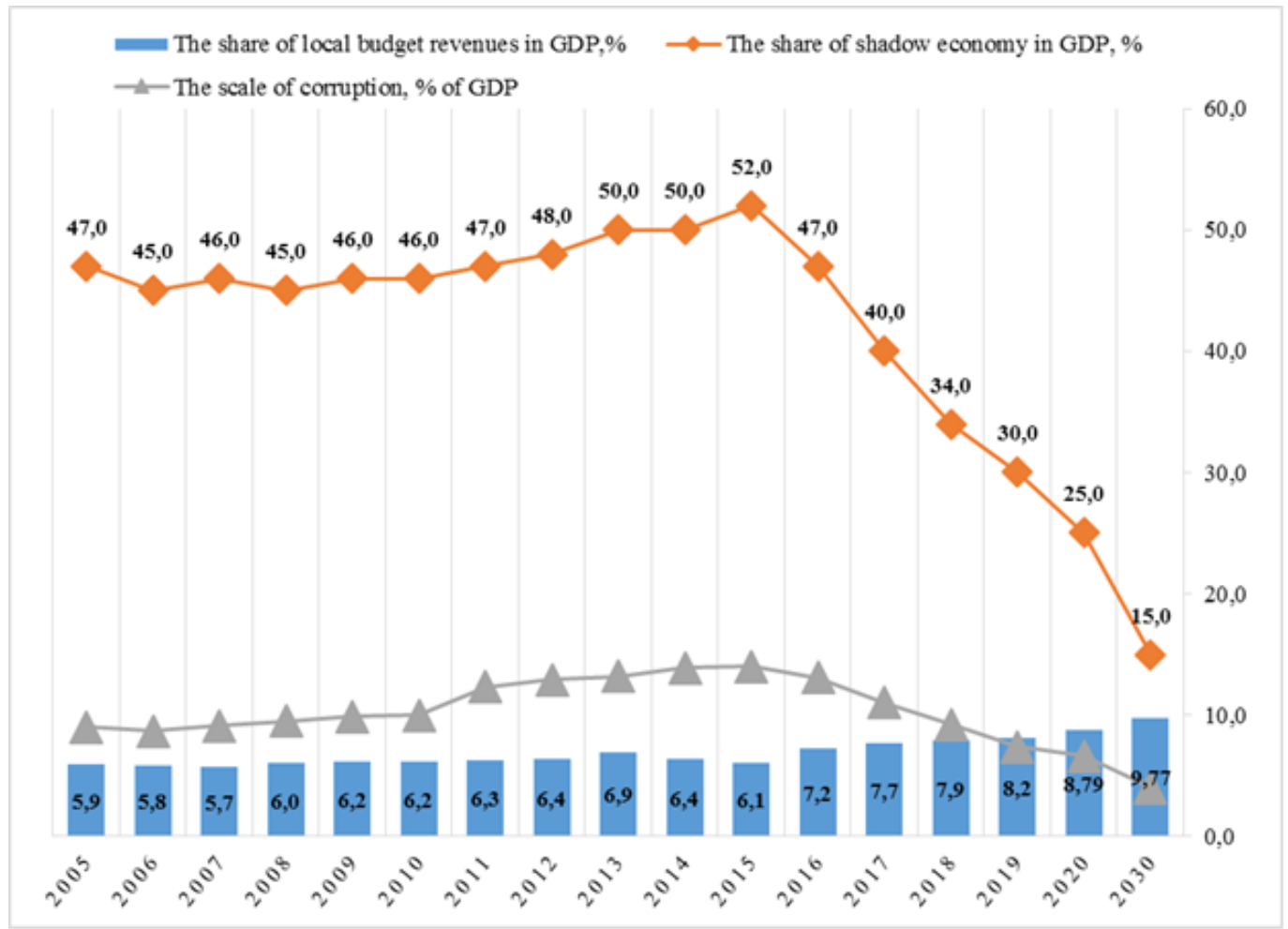

Fig. 5. Dependence of changes in the volume of local budgets revenues of Ukraine on the changes of fiscal space (particularly, the volume of the share of the shadow sector in GDP and the scale of corruption in the economy of Ukraine)*

* 2019-2030 - projected data.

Source: Created by the authors.

The projected assumptions about the financial sustainability of local budgets in Ukraine should be seen as a result of acceptable estimates of changes in the amount of local budget revenues in Ukraine from changes in the fiscal space, accepted 
assumptions taking into account the prerequisites for negative impact of risks, in particular the shadow sector and the scale of corruption in the Ukrainian economy, and the positive impact of factors such as budget decentralization.

\section{Conclusions.}

It is substantiated that fiscal space provides opportunities for local governments to obtain and use additional budgetary resources to achieve the goal, taking into account the constraints caused by the need to maintain financial sustainability in the mid- and longterm periods. The article presents a set of arguments about the feasibility of the use of the methodology of calculating the financial sustainability of local budgets of the European Commission in the mid-term period $\left(\mathrm{S}_{1}\right)$ in the national practice. Based on the development of the regressive model, the dependence of changes in local budget expenditures (relative to GDP) on their own revenues as a share of GDP is conducted. The logarithmic trend showed a downward trend in the sustainability of local budgets in Ukraine in the mid-term period, thus, it demonstrated a decrease of this indicator. It is proved that the analyzed methodology of the European Commission is too simplistic to determine the long-term indicator of financial sustainability of local budgets only due to the characteristic of the ratio between revenues and expenditures of the budget (relative to GDP). This methodology does not take into account the indicators of the fiscal space of the budget, its autonomy, efficiency, debt load and other factors, in particular - changes in the formation of revenues and expenditures of local budgets as due to possible prospects for innovative development in the particular territory, as well as positive results or negative consequences for the development of the territorial community in the context of decentralization.

It is substantiated that the development of strategic directions for ensuring the long-term financial sustainability of local budgets in Ukraine in the context of decentralization should be done with the use of foresight for each regional or territorial community budget. The foresight methodology of financial sustainability of local budgets based on the Delphi method, the SWOT-analysis method and the scenarios development methods is proposed. This methodology is proposed to use in the mid- and long-term periods to calculate the financial sustainability of local budgets of Ukraine at the level of regions or territorial communities. Foresight differs from other forecasting mechanisms in that, unlike predictions that correlate predominantly with predictions of low-level events, the potential perspectives for innovative development in the particular territory and the positive outcomes for the development of the territorial community are estimated during foresight. Foresight is a system of methods for expert assessment of strategic directions of social-economic and innovation development, as well as the identification of technological penetration that can affect the development of a region or territory in the mid- and long-term perspectives.

\section{References}

Bondaruk, T. H. (2017), “Theoretical principles of financial stability of local budgets”, Current Trends in Economics and Management, Collection of materials international scientific and practical conference, Zaporizhzhia, Ukraine, June 30, 2017, Part 2, pp. 9-10.

Boothe, P. (2003), "Taxing, spending and sharing in federal countries: Evidence from Australia and Canada", in: Boothe, P. (ed.) (2003), Fiscal relations in federal countries: Four essays, Forum of Federations, Ottawa, Canada, $54 \mathrm{p}$.

European Commission (2012), "Fiscal sustainability report 2012", European Economy, no. 8, 204 p. doi: http://doi.org/10.2765/19669

European Commission (2014), "Identifying fiscal sustainability challenges in the areas of retirement, health care and long-term care policies", Occasional Papers, no. 201, 45 p. available at https://ec.europa.eu/economy finance/publications/occasional_paper/2014/pdf/ocp201_en.pdf (Accessed 20 April 2020). 
International Monetary Fund (2010), “The IMF-FSB early warning exercise: Design and methodological toolkit”, available at: http://www.imf.org/external/np/pp/eng/2010/090110.pdf (Accessed 20 April 2020).

Korytko, T. Yu. (2008), "Methods of estimation of financial sustainability of local budgets", Economic space, no. $12 / 1$, pp. $140-154$.

Mykytiuk, I. (2013), "Financial sustainability and security of the local budget”, Bulletin of the Kyiv National University of Trade and Economics, no. 1, pp. 87-96.

Polyak, G. B. (2000), Byudzhetnaya sistema Rossii [Budget system of Russia], Unity Dana, Moscow, Russia, $550 \mathrm{p}$.

President of Ukraine (2015), Decree of the President of Ukraine "Ukraine 2020 Sustainable Development Strategy”, available at: http://zakon4.rada.gov.ua/laws/show/5/2015 (Accessed 20 April 2020).

Serohin, S. M. and Sharov, Yu. P. (Eds.) (2016), Upravlinnia stratehichnym rozvytkom ob'iednanykh terytorialnykh hromad: innovatsiini pidkhody ta instrumenty [Management of strategic development of united territorial communities: Innovative approaches and tools], DRIDU NADA, Dnipro, Ukraine, 276 p.

The Verkhovna Rada of Ukraine (2014), Resolution of the Verkhovna Rada of Ukraine "Program of activity of the Cabinet of Ministers of Ukraine", available at: https://zakon.rada.gov.ua/laws/show/26-19\#Text (Accessed 20 April 2020).

Umanskyi, I. I. (2015), “The stability of public finances in the context of European integration processes”, Finance of Ukraine, pp. 9-28.

Yefymenko, T. I. (2011), “Formation of fiscal space of economic reforms”, Finances of Ukraine, no. 1, pp. 3-23. Zhurovskyi, M. Z. (ed.) (2015), Forsait ekonomiky Ukrainy: serednostrokovyi (2015-2020 roky) i dovhostrokovyi (2020-2030 roky) chasovi horyzonty [Foresight of the Ukrainian economy: mid-term (2015-2020) and long-term (2020-2030) time horizons], NTUU “KPI”, Kyiv, Ukraine, 136 p.

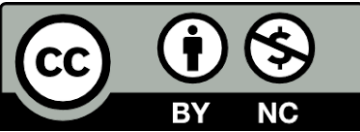

Цей твір ліцензовано на умовах Ліцензії Creative Commons «/з Зазначенням Авторства - Некомериійна 4.0 Міжнародна» (CC BY-NC 4.0). This is an open access journal and all published articles are licensed under a Creative Commons "Attribution-NonCommercial 4.0 International" (CC BY-NC 4.0). 